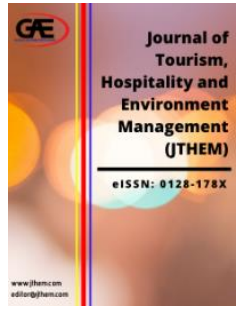

\author{
JOURNAL OF TOURISM, \\ HOSPITALITY AND \\ ENVIRONMENT MANAGEMENT \\ (JTHEM) \\ www.jthem.com
}

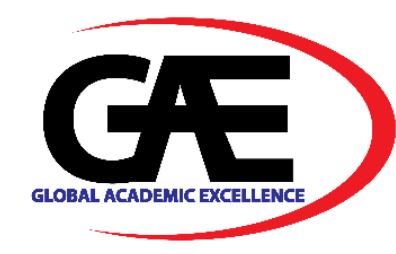

\title{
CHOICE OF TRANSPORTATION MODE - A THEORETICAL STUDY
}

\author{
Nabihah Kamarudin ${ }^{1 *}$, Gobi Krishna Sinniah ${ }^{2}$ \\ 1 Department of Urban and Regional Planning, Universiti Teknologi Malaysia, Malaysia \\ Email: nabihahkmrd@gmail.com \\ 2 Department of Urban and Regional Planning, Universiti Teknologi Malaysia, Malaysia \\ Email: sgobi@utm.my \\ * Corresponding Author
}

\section{Article Info:}

Article history:

Received date: 01.10 .2021

Revised date: 01.11.2021

Accepted date: 15.11 .2021

Published date: 01.12.2021

\section{To cite this document:}

Kamarudin, N., \& Sinniah, G. K. (2021). Choice Of Transportation Mode - A Theoretical Study. Journal of Tourism Hospitality and Environment Management, 6 (26), 242-252.

DOI: 10.35631/JTHEM.626022.

This work is licensed under $\mathrm{CC}$ BY 4.0

\begin{abstract}
:
Inefficient public transport is considered a normal problem in any city or country. The motivations of transportation users determine their choice of transportation mode. This paper is aimed to identify the reasons behind the choice of transportation mode among daily commuters. Specifically, this paper observes the quality of public transport offered towards the users and how it affects their decision on the transportation mode. To understand their motivations, a literature review study has been conducted to interpret their preferences on the quality of public transport. The result shows the indicators that can be measured in the quality of public transport. Several past kinds of research have discussed the measures in solving issues related to public transport to encourage people to use the service given.
\end{abstract}

Keywords:

Factors, Transportation, Passengers, Users, Commuters

\section{Introduction}

Public transport is an infrastructure that is provided to facilitate users in mobility. Buses, trains, ferries and airlines are examples of public transport. 


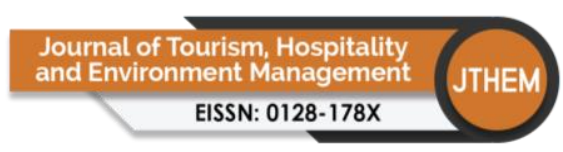

Volume 6 Issue 26 (December 2021) PP. 242-252

DOI 10/35631/JTHEM.626022

According to Walker (2008), there are two main purposes of provision of public transport, which are; served by patronage and served by coverage. These two purposes have their own goals, whereas the patronage aims to create income and have their own agenda, while serving for coverage is mainly to ease the daily commuters.

Normally, public transport in cities focused on providing a high accessibility between land uses. Public transport accessibility is addressed to contribute in declining the congestions and number of private vehicles on the road, as well as high connectivity (Saif, Zefreh and Torok, 2017). A good planning and networking of public transportation could be attractive when it considers the coverage and catchment areas.

Malaysia aimed to have more public transport users in 2020. There are several public transports operated in Malaysia, especially in urban areas; commuter trains, bus light rail transit and more. One of the most important tasks of public transportation is to assist individuals who cannot afford a car in getting to job, school, family, friends, and other everyday requirements (Spieler, 2018). However, the situation and condition of public transport itself could not attract people to choose public transport as their transportation mode. Due to the continuing development of Malaysia's metropolitan population, building a high-quality public transportation infrastructure is challenging (Mohamed Irtema et al., 2018).

Several indicators are being considered by commuters in choosing their mode of transport for daily activities, such as travel behaviour, accessibility, reliability and physical conditions. In this paper, it discussed only about the quality of the public transport offered; accessibility, reliability and physical condition.

\section{Indicators}

In this paper, there are three indicators chosen to evaluate the factors that influence transportation mode among users based on literature review that has been made. Accessibility is the most important aspect in evaluating any transportation mode. The convenience with which specific areas can be reached by foot or public transportation is measured by accessibility (Puspas, 2020). In accessibility, there are two sub indicators that are being measure; access to the public transport and access to destination. Previous studies showed the accessibility is the major factor of the choice of transportation mode.

Since there are no public transportation linkages between places where an individual needs to travel, public transportation is not adaptable to times when individuals want to travel (Berg and Ihlström, 2019). Secondly, reliability is being measured and divided into several sub indicators. According to Firew (2016), Passengers may have longer wait times, longer journey times, trouble making transfers, overcrowding, and unhappiness with the service as a result of service unreliability. Therefore, punctuality, frequency, travel time, safety, transportation hub facilities and availability of information are the sub indicators that are essential to be measured. Physical condition is the least important indicator but it affects the motivation of users as well. Physical characteristics are measured without the participation of public transportation customers, and assumptions are made regarding the effects on them (Redman at al., 2013). 


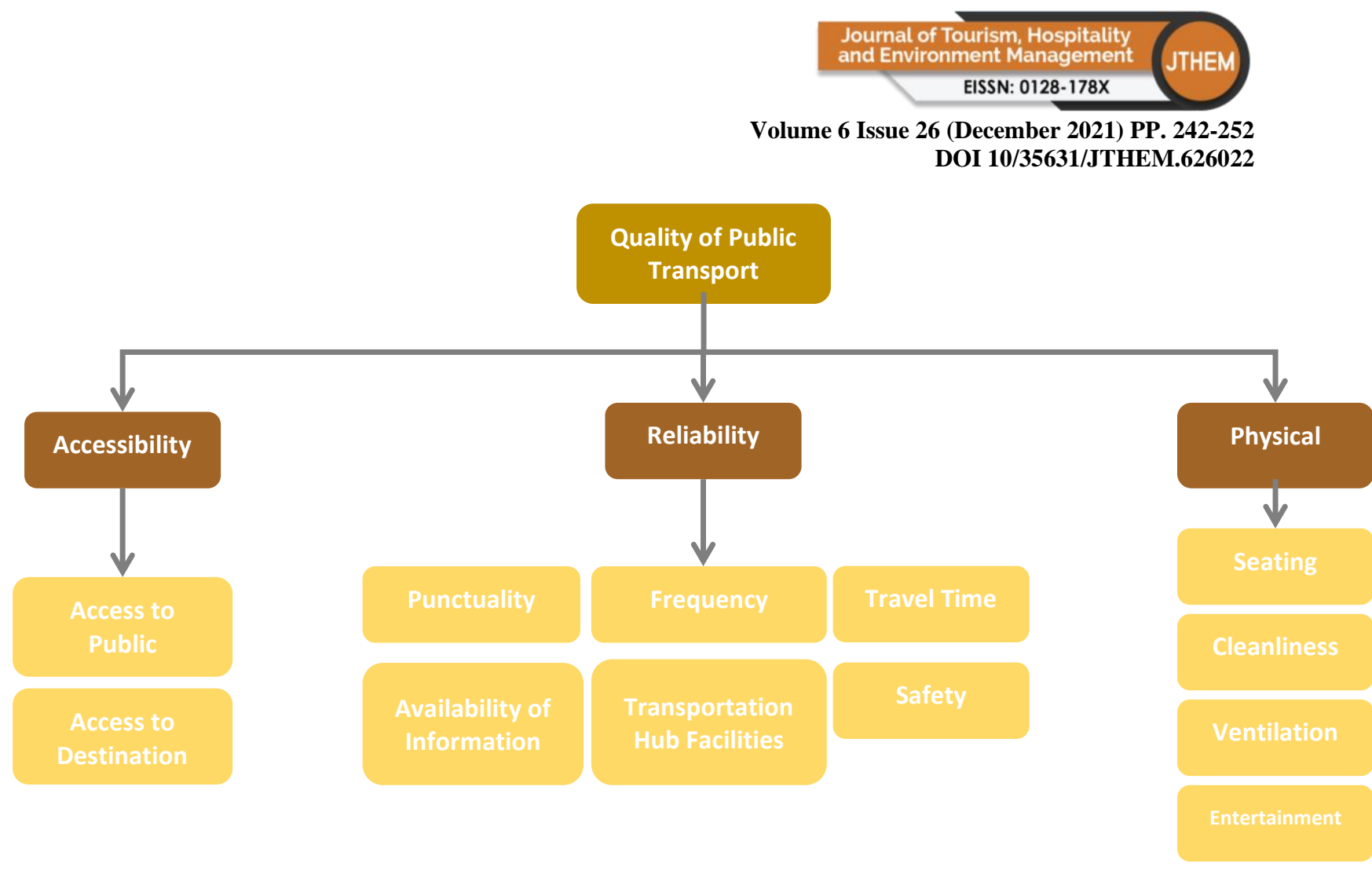

Source: by author

Figure 1: Indicators of Quality of Public Transport

\section{Accessibility}

\section{Access to Public Transport}

High accessibility to public transport attracts users to rely on the service. This means, considering the land uses in planning the route of public transport is important to serve and meet the needs of users. Public transport should be designed to meet the needs, whereas it should be interconnected between residential areas and other land uses (Ustadi and Mohammad Shopia, 2016).

Another alternative that can be considered by public transport planners is by providing a safe, resilient and enough facilities. Designing such a permeable and walkable pedestrian and the public transport services could interest the users (Chowdury, Zhai and Khan, 2016). The walking distance between land uses and the service should be reachable by pedestrians, which means the distance is ideal enough for users to walk. According to Hanssons et al. (2019), the estimation for an ideal walk distance should be roughly around 5 minutes' walk or $400 \mathrm{~m}$ to $800 \mathrm{~m}$.

The condition of the environment could influence people's perspective. Therefore, it is also necessary to look at the safety of the pedestrian walkway. Streets that are full with activities could make users to feel secure and comfortable (Chowdury, Zhai and Khan, 2016).

\section{Access to Locations}

The coverage of public transport influenced the choice of transportation mode among users. Providing a better coverage and reducing road congestion is the main objective of planning a public transport (Saif, Zefreh and Torok, 2017). Urban areas are most likely to have a good coverage of public transport compared to rural areas due to the demand. 


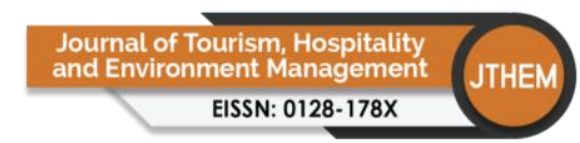

Volume 6 Issue 26 (December 2021) PP. 242-252

DOI 10/35631/JTHEM.626022

In addition, urban areas are heading to meet the smart growth concept, which means, it requires less mobility to reach the required destination (Littman, 2021). Prior to plotting the position for public transit, it is critical to emphasize the activities of the areas in order to achieve smart growth. The key reasons for evaluating the accessibility of public transportation are to minimise the use of private vehicles that can caused traffic congestion on the road by increasing their connectivity and providing a proper location for each station (Saif, Zefreh and Torok, 2018).

\section{Reliability}

\section{Punctuality}

Punctuality of a public transport is measured by the time arrival of the transport as per schedule. Those people who chose private vehicle over public transport is mainly because they concern on the punctuality of the transport (Borhan et al., 2017). In Khalid et al. (2014), KTM Komuter service real problem is punctuality and the timing became poorer. This issue influenced users to switch the transportation mode and made them give a bad impression towards this service. In addition, it also contributed to a high number of passengers as well due to waiting for a long time.

There are two factors that affecting the punctuality of public transport; the public transport operator and unexpected circumstances (Salicru et al., 2015). Transport operator refers to the schedule of the public transport, route, behaviour of drivers and more. Meanwhile, unexpected circumstances such as accidents, traffic jams and vehicle breakdown could also happen beyond their capability.

However, based on the previous studies regarding this issue, most cases involving punctuality refers to the transport operator itself. Lack of punctuality could affect the satisfaction of users. (Monsuur et al., 2017).

\section{Frequency}

Frequency is constantly related with the time schedule of the public transport. Low frequency of public transport could affect the reliability (Bajada and Titheridge, 2016). A study was conducted by Ummi Aqilah Khalid et al., (2014), regarding the KTM service in Kuala Lumpur, the frequency of the train is 15 minutes during peak hours while regular time is 30 minutes. Compared to train service in Singapore, the frequency only takes about every 3 to 5 minutes. Long gap of frequency could also affect the condition inside the public transport. As KTM Komuter is one of main public transport in Kuala Lumpur, the number of passengers is high. The delay or long gap of frequency of this train creates another problem - overcrowded in train makes users feel uncomfortable.

Another study was conducted in Putrajaya, $80 \%$ of car users choose to ride their own vehicle due to low frequency of public transport (Borhan et al., 2017). They are mostly concern on the time they will consume if they choose to use public transport to travel. Therefore, to reduce their time travel, their choice of travel mode is by using their own cars which is more efficient.

However, the frequency of public transport is correlated with the demand of users (Borhan et al., 2017). Service frequency is often decisive by the accumulated hourly passenger counts, 


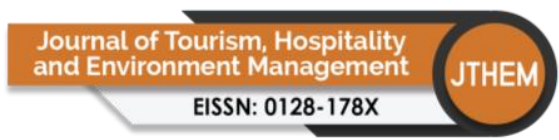

Volume 6 Issue 26 (December 2021) PP. 242-252

DOI 10/35631/JTHEM.626022

average travel time, vehicle capacity and the minimum allowed frequency limit by time of day (Gkiotsalitis and Cats, 2017). In addition, the transport operator also considers the costs that they needed to invest to have such a high frequency to meet the demand. In other words, the higher the frequency, the higher the cost. The frequency of public transport is determined by the importance of the destinations along the route (Tubis, and Gruszczyk, 2015).

\section{Travel Time}

Travel time affects the motivations of users in choosing the transportation mode. A long travel time makes commuters feel demotivated to use public transport. A long travel time in public transport may cause commuters to shift the transportation mode to private vehicles in order to avoid their stress in commuting (Borhan et al., 2017). Most users that choose private cars is because it is more time - efficient compared to public transport (Almselati, Rahmat \& Jaafaret, 2011). To attract users to choose public transport, the travel time should be lesser than private vehicles. Just like in Japan, the efficiency of public transport is much higher compared to private vehicle. Accessibility enhancement needed to be done to shorten the time constraints and encourage a flexible planning (Littman, 2021).

Travel time is closely related with other factors; frequency, facilities and information on the service. Frequency and time table of transport service plays a major role and affects the travel time. This is because the time table of the service has been planned based on the demand and vehicles supply available (Salicru et al., 2011). Particularly, the lower the frequency, the longer the travel time.

Inefficient facilities could confuse users especially in their first time of travelling and it affects the travel time due to their late arrival to get in the bus (Minhans, Shahid and Ahmed, 2014). This is also implemented to the people with disability, whereby the transportation hub or the transport itself are not considering this group of people. Disabled people are often helpless when the service does not provide a proper facility for them (Gkiotsalitis and Cats, 2017).

Availability and updated information on the public transport service is important for users to acknowledge on the status of the service. Complaints were made on the public transport, whereby the information of the service is not being updated time to time and leads to longer travel time (Minhans, Shahid and Ahmed, 2014; Borhan et al., 2017). Without such information, users will mistakenly take the available information while the service has been adjusted.

\section{Transportation Hub Facilities}

There are various facilities provided in transportation hub, such as signage, time table and more. However, the reliability of these facilities is essential to assists users and to determine the reliability of these facilities can be measured on how efficient it is in assisting users. It is found that transportation hub is mostly makes children, disabled people and people with heavy loads feel burdensome due to non-user friendly of facilities provided (Littman, 2021). This difficulty will lead to the delay of the journey.

Facilities like a proper and adequate pedestrian walkway and bus stop should be provided by the authorities to encourage people in commuting with public transport (Borhan et al., 2017). The paved pathway should be free from any potholes to avoid injuries towards users, while the 
bus stop should be designed with weather resilience concept - especially when there is heavy raining.

Meanwhile, an appropriate park and ride also encourage users to change the transportation mode. To make the park and ride interesting enough, a convenient road access and parking must be designed in such a high accessibility integrated with the terminal hub (Littman, 2021).

Others additional facilities with the purpose of entertainment like $\mathrm{WiFi}$, music and air conditioning system (Mugion et al., 2018) could promote the service as well. It is believed that a functional facility could encourage people to use the public transport (Ustadi and Mohammad Shopia, 2016).

\section{Availability of Information}

Time schedules of public transport and delay should be announced to acknowledge users. It is important for users because some of them plans their travel trip. There are many ways to give information towards users, whether it is by providing schedules at the terminal hub, announcement or through online.

According to Khalid et al. (2014), study shows that KTM Komuter service has been reportedly to have announcement on the delay or any changes on the schedule. Nowadays, information displays through online is much reliable because people are going forward to technologies. With this advantage, it could help users to plan their travel without consuming so much time waiting for the transport (Borhan et al., 2017).

However, lack of availability of information could cause a feeling of insecurities among women. A study was conducted by Rohana Sham, Nurazlina Samsudin and, Khairunnisa Rahman, (2013) on the travel fear among women in Penang, the respondents contended that unavailability of sufficient information makes them feel vulnerable. This is because they had to wait longer at the bus stop and rescheduling their trip.

Lack of information may dishearten users and finally demotivate them from using public transport (Borhan et al., 2017). Updating information from time to time may influence them on the reliability of the transportation service offered.

\section{Safety}

Safety issue in commuting public transport is mostly concerned among women. However, this does not mean men is exceptional. Infrastructure design, punctuality, comfort, security and information availability are factors that contributing towards safety issues (Rohana Sham, Nurazlina Samsudin and, Khairunnisa Rahman, 2013).

Infrastructure design is the most important issue that related with safety. Pedestrian walkway is supposed to be designed integrated with the bus stop to ensure the safety users. This is because some users criticized that the facilities are not being provided very well that they had to cross the hectic traffic just to reach the bus stop (Borhan et al., 2017). The kind of situation will harm users while commuting.

Comfort and security aspect in safety mostly by means the behaviour of the drivers and facilities. The attitude of driver during driving influences the experience of passengers (Bajada 


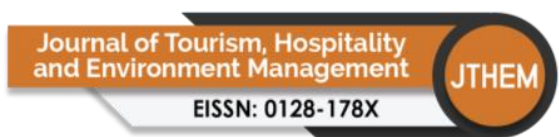

Volume 6 Issue 26 (December 2021) PP. 242-252

DOI 10/35631/JTHEM.626022

and Titheridge, 2017). Feeling secure and convenience during travelling is highly affected by the behaviour of bus driver (Minhans, Chatterjee and Popli, 2020). Reckless driving behaviour by bus drivers and traffic offence on the road makes passengers feel insecure and unsafe, especially among women (Borhan et al., 2017). Poor driving skills makes people think that it is safer if they drive by themselves. Therefore, to promote such a safe and secure public transport, it is crucial to educate drivers regarding this issue. This idea has been introduced by Joewono and Kubota (2005), educating and coaching in driving skills as a strategy to improve the safety is important.

Bus terminal and inside the public transport itself may cause the feeling of unsafe. Installing CCTV, a good lighting of the building or transport and availability of security staff (Minhans, Chatterjee and Popli, 2020) could help in reducing any crime and vulnerability. Promoting public transport service without considering safety issues will only abuse the commuters.

\section{Physical Condition}

Physical condition is associated with comfort - whereas the comfort is felt by the passengers. According to a study by Minhans, Chatterjee and Popli (2020), there are four aspects that users considered regarding the physical conditions, which is; seating, cleanliness, air conditioner, and entertainment. However, these attributes may be viewed differently according to each respondents' priority, depends on the background of the respondents. These aspects are not only applicable for public transport, but the transportation hub as well.

Cleanliness is the main aspects that will be valued in the physical condition. Study shows that satisfaction of public transport users depends on the cleanliness and capacity area of the public transport influenced their motivation to use it. Waiting areas at bus terminal with sufficient amount of seating for users creates a pleasing environment for them (D.-T. Le-Klähn, C. M. Hall, and R. Gerike, 2014). Passengers will definitely feel at ease when the facilities provided are comfortable and enough for them.

However, small spaces or low-capacity areas will make users uncomfortable. Providing a high frequency of public transport could overcome this issue especially during peak hours. Experiencing a high capacity of public transport will make users feel uncomfortable because of overcrowding (Bajada and Titheridge, 2016). The capacity for transportation hub also needed to be planned very well when the hub perceived such a high number of users. Therefore, upgrading the public transport and transportation hub is a must to ensure the passengers feel comfortable (Rohana Sham, Nurazlina Samsudin, Khairunnisa Rahman, 2013). 


\begin{tabular}{|c|c|c|c|}
\hline Reference & $\begin{array}{l}\text { Categories of } \\
\text { Indicators }\end{array}$ & Indicators & Description \\
\hline $\begin{array}{l}\text { Speck (2004); } \\
\text { Chowdhury, Zhai } \\
\text { and Khan (2016); } \\
\text { Ustadi and } \\
\text { Mohammad } \\
\text { Shopia (2016); } \\
\text { Hansson et al., } \\
\text { (2019) }\end{array}$ & Accessibility & $\begin{array}{l}\text { Access to } \\
\text { Public } \\
\text { Transport }\end{array}$ & $\begin{array}{l}\text { - } \\
\text { - } \text { Integrated network } \\
\text { and permeable } \\
\text { design of street } \\
\text { - Walking condition } \\
\text { and pedestrian } \\
\text { walkway } \\
\text { - Distance for walking } \\
\text { areas }\end{array}$ \\
\hline $\begin{array}{l}\text { Saif, Zefreh and } \\
\text { Torok, (2017); } \\
\text { Littman (2021) }\end{array}$ & & $\begin{array}{l}\text { Access to } \\
\text { Locations }\end{array}$ & $\begin{array}{ll}\text { - } & \text { Network coverage } \\
\text { - } & \text { Smart growth } \\
\text { - } & \text { Location of station }\end{array}$ \\
\hline $\begin{array}{l}\text { Khalid et al. } \\
\text { (2014); Salicru et } \\
\text { al., (2015); Borhan } \\
\text { et al., (2017); } \\
\text { Monsuur et al., } \\
\text { (2017) }\end{array}$ & Reliability & Punctuality & $\begin{array}{l}\text { - } \begin{array}{l}\text { Concern on the time } \\
\text { consumed while } \\
\text { travelling }\end{array} \\
\text { - Case study: KTM } \\
\text { Komuter } \\
\text { - Situations that affect } \\
\text { the punctuality of } \\
\text { public transport } \\
\text { - Level of satisfaction } \\
\text { of users in } \\
\text { punctuality }\end{array}$ \\
\hline $\begin{array}{l}\text { Tubis, and } \\
\text { Gruszczyk, (2015); } \\
\text { Borhan et al., } \\
\text { (2017); Gkiotsalitis } \\
\text { and Cats, (2017) }\end{array}$ & & Frequency & $\begin{array}{l}\text { - The demand affects } \\
\text { the frequency of the } \\
\text { transit } \\
\text { - The calculation for } \\
\text { frequency of the } \\
\text { transit }\end{array}$ \\
\hline $\begin{array}{l}\text { Almselati, Rahmat } \\
\text { \& Jaafaret, (2011); } \\
\text { Minhans, Shahid } \\
\text { and hmed (2014); }\end{array}$ & & Travel Time & $\begin{array}{l}\text { Effects of long travel } \\
\text { time towards users }\end{array}$ \\
\hline
\end{tabular}


Volume 6 Issue 26 (December 2021) PP. 242-252 DOI 10/35631/JTHEM.626022

\begin{tabular}{|c|c|c|}
\hline $\begin{array}{l}\text { Borhan et al., } \\
\text { (2015); Gkiotsalitis } \\
\text { and Cats, (2017); } \\
\text { Littman, (2021) }\end{array}$ & & 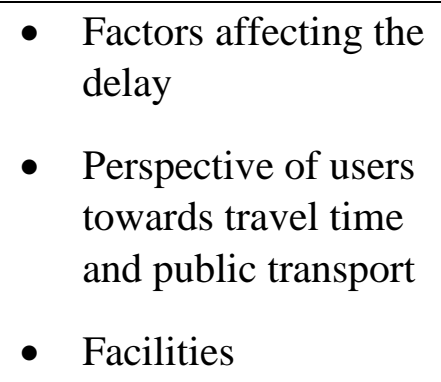 \\
\hline $\begin{array}{l}\text { Ustadi and } \\
\text { Mohammad } \\
\text { Shopia, (2016); } \\
\text { Borhan et al., } \\
\text { (2017); Mugion et } \\
\text { al., (2018); Littman } \\
\text { T., (2021) }\end{array}$ & $\begin{array}{l}\text { Bus Terminal } \\
\text { Facilities }\end{array}$ & $\begin{array}{l}\text { - } \begin{array}{l}\text { Park and ride } \\
\text { facilities }\end{array} \\
\text { - } \quad \text { Bus stop and } \\
\text { pedestrian walkway } \\
\text { - } \text { Entertainment } \\
\text { - } \text { The infrastructure } \\
\text { design inside the } \\
\text { terminal } \\
\text { - The accessibility } \\
\text { towards facilities at } \\
\text { terminal } \\
\text { - Importance of } \\
\text { functional facilities }\end{array}$ \\
\hline $\begin{array}{l}\text { Rohana Sham, } \\
\text { Nurazlina } \\
\text { Samsudin and, } \\
\text { Khairunnisa } \\
\text { Rahman, (2013); } \\
\text { Khalid et al. } \\
\text { (2014); Borhan et } \\
\text { al., (2017); }\end{array}$ & $\begin{array}{l}\text { Availability of } \\
\text { Information }\end{array}$ & $\begin{array}{l}\text { - Case study: KTM } \\
\text { Komuter } \\
\text { - Suggestion on } \\
\text { updating through } \\
\text { online to ease users } \\
\text { in planning their trip } \\
\text { - Women's fear - lack } \\
\text { of information makes } \\
\text { them wait longer at } \\
\text { the bus stop }\end{array}$ \\
\hline $\begin{array}{l}\text { Joewono and } \\
\text { Kubota (2005); } \\
\text { Borhan et al., } \\
\text { (2017); Bajada and } \\
\text { Titheridge, (2017); } \\
\text { Minhans A., } \\
\text { Chatterjee A. and } \\
\text { Popli S. (2020); }\end{array}$ & Safety & $\begin{array}{l}\text { - Women's concern on } \\
\text { safety } \\
\text { - Drivers' behaviour } \\
\text { on the road affects } \\
\text { passengers' } \\
\text { experiences }\end{array}$ \\
\hline
\end{tabular}


Volume 6 Issue 26 (December 2021) PP. 242-252

DOI 10/35631/JTHEM.626022

\begin{tabular}{|c|c|c|c|}
\hline & & & $\begin{array}{l}\text { - } \begin{array}{l}\text { Educating the drivers } \\
\text { on safety }\end{array} \\
\text { - Suggestion on } \\
\text { installing equipment } \\
\text { like CCTV and good } \\
\text { lighting as well as } \\
\text { security staff }\end{array}$ \\
\hline $\begin{array}{l}\text { Rohana Sham, } \\
\text { Nurazlina } \\
\text { Samsudin, } \\
\text { Khairunnisa } \\
\text { Rahman, (2013); } \\
\text { D.-T. Le-Klähn, C. } \\
\text { M. Hall, and R. } \\
\text { Gerike, (2014); } \\
\text { Bajada and } \\
\text { Titheridge, (2016); } \\
\text { Minhans, } \\
\text { Chatterjee and } \\
\text { Popli (2020); }\end{array}$ & $\begin{array}{l}\text { Physical } \\
\text { Condition }\end{array}$ & $\begin{array}{l}\text { Seating, } \\
\text { cleanliness, } \\
\text { ventilation and } \\
\text { entertainment }\end{array}$ & $\begin{array}{l}\text { - Aspects on physical } \\
\text { condition } \\
\text { - Good facilities - } \\
\text { pleasing environment } \\
\text { - Overcrowding - } \\
\text { unpleasant feelings } \\
\text { among passengers } \\
\text { - Upgrading the } \\
\text { facilities to increase } \\
\text { the level of comfort }\end{array}$ \\
\hline
\end{tabular}

Table 1: Summary of Previous Study on The Factors of Transportation Mode Choices

\section{Conclusion}

This study is significantly used to determine and evaluate the aspects that is considered in choosing a transportation mode by daily commuters. The indicators that are selected to understand the motivations of users are based on the emphasis of several literature reviews and studies. It is necessary to understand their motivation in order to provide and improve a better transportation system. Therefore, this study is relevance and can be applied to study the users' motivation to switch the transportation mode from private vehicle to public transport.

\section{Acknowledgement}

The authors would like to express their appreciation for the support from Universiti Teknologi Malaysia for this Project - The Motivations of Nature-Based Tourists to Use Public Transport.

\section{References}

An Overview of Public Transportation Services as an Attraction of Tourism Industry in Malaysia. (2019). Public Transport, 191-194.

Bajada, T., \& Titheridge, H. (2017). The attitudes of tourists towards a bus service: implications for policy from a Maltese case study. Transportation Research Procedia, $25,4110-4129$.

Borhan, M. N., Ibrahim, A. N. H., Syamsunur, D., \& Rahmat, R. A. (2017). Why Public Bus is a Less Attractive Mode of Transport: A Case Study of Putrajaya, Malaysia. Periodica Polytechnica Transportation Engineering, 47(1), 82-90.

Chiu Chuen, O., Karim, M. R., \& Yusoff, S. (2014). Mode Choice between Private and Public Transport in Klang Valley, Malaysia. The Scientific World Journal, 2014, 1-14. 
Eboli, L., \& Mazzulla, G. (2007). Service Quality Attributes Affecting Customer Satisfaction for Bus Transit. Journal of Public Transportation, 10(3), 21-34.

Gkiotsalitis, K., \& Cats, O. (2017). Exact optimization of Bus Frequency Settings considering Demand and Trip time variations. Exact Optimization of Bus Frequency Settings Considering Demand and Trip Time Variations, 2-15.

Gutiérrez, A., \& Miravet, D. (2016). The Determinants of Tourist Use of Public Transport at the Destination. Sustainability, 8(9), 908.

Identifying key factors for the successful provision of public transport for tourism. (2015). Orsi Francesco (Ed.): Sustainable Transportation in Natural and Protected Areas, 1-9.

Ismail, I. K., Hoon Leh, O. L., \& Ahmad Zaki, Z. (2017). An Evaluation Of Urban Public Transport Route. Case Study: Hop-On Hop-Off, Kuala Lumpur, Malaysia. Planning Malaysia Journal, 16(6), 2-39.

Joewono, T. B., \& Kubota, H. (2006). Safety And Security Improvement In Public Transportation Based On Public Perception In Developing Countries. IATSS Research, 30(1), 86-100.

Khalid, U. A., Bachok, S., Osman, M. M., \& Ibrahim, M. (2014). User Perceptions of Rail Public Transport Services in Kuala Lumpur, Malaysia: KTM Komuter. Procedia Social and Behavioral Sciences, 153, 566-573.

Kovačić, M., \& Milošević, T. (2016). Interdependence of Transport and Tourism. Journal of Maritime \& Transportation Science, 52(1), 99-111.

Le-Klähn, D.-T., \& Hall, C. M. (2014). Tourist use of public transport at destinations - a review. Current Issues in Tourism, 18(8), 785-803.

Minhans, A. (2020). Public perceptions: an important determinant of transport users' travel behaviour. Human Geographies - Journal of Studies And Research In Human Geography, 14(2), 178-192.

Saif, M. A., Zefreh, M. M., \& Torok, A. (2018). Public Transport Accessibility: A Literature Review. Periodica Polytechnica Transportation Engineering, 47(1), 36-43.

Sham, R., Samsudin, N., \& Rahman, K. (2013). Managing Public Transport Service Operation in Reducing Travel Fear Factor. Procedia - Social and Behavioral Sciences, 101, 338 344. 